\title{
Barrier-Free Accessible Environment and Kamlapur Railway Station - Require to More Sustainable
}

\author{
Md. Mustafizur Rahman ${ }^{1, ~ *, ~ N o b u a k i ~ O h m o r i ² ~}$ \\ ${ }^{1}$ Department of Architecture, Shahjalal University of Science and Technology, Sylhet, Bangladesh \\ ${ }^{2}$ Department of Urban Engineering, the University of Tokyo, Tokyo, Japan
}

Email address:

mustafiz_su@yahoo.com (Md. M. Rahman)

*Corresponding author

\section{To cite this article:}

Md. Mustafizur Rahman, Nobuaki Ohmori. Barrier-Free Accessible Environment and Kamlapur Railway Station - Require to More Sustainable. International Journal of Architecture, Arts and Applications. Vol. 3, No. 2, 2017, pp. 21-30. doi: 10.11648/j.ijaaa.20170302.12

Received: February 10, 2017; Accepted: March 15, 2017; Published: May 6, 2017

\begin{abstract}
There is, however, limited knowledge of how precisely the needs of disabled people are defined and incorporated, or not, into the design and development for the accessible environment [1]. This study assumes that the accessible design in public places facilities are of benefit not only to disabled people but all people with the diversity. Thus the significance of the proposed barrier-free design is to focus on benefits of the accessible plan to a variety of people. Accessibility in public places has previously been regarded as an additional services designed especially for those who cannot manage ordinary facilities. Now to design accessible environment in public places is an important issue to maintain the sustainability of our society [1]. Therefore this paper aims to investigate the barriers and deficiencies for disable people found in railway station and then to provide valuable information on effective design techniques and principles for ensuring barrier-free accessible environment in public places.
\end{abstract}

Keywords: Barrier-Free Design, Railway Station, Public Places, Accessible Environment

\section{Introduction}

Today, barrier free accessible environment in every public places is an important issue to maintain the sustainability of our society. In developed country, laws and regulations order all new public places facilities be accessible and design companies are now trying to introduce accessibility into existing facilities [2]. The experience so far teaches us that it is easy to realize an accessible facility when the facility is newly constructed but it is strenuous and expensive to introduce accessibility into existing facilities, especially large public places facilities such as railway stations. Under such a difficult situation, a detailed evaluation tool for accessible designs may be of use to the design of the introduction of accessible environment. Therefore accessible environment is the passport to independent living for everyone and barrierFree design means giving users the ability to move around without restriction [3]. The term barrier-free design is commonly interpreted as removing physical and attitudinal obstacles that prevent the free movement of persons with disabilities in a manner that is consistent with regulations and standards. This is especially true of disabled passengers, who may have particular concerns about the accessibility of the stations they will be using. In addition Potential passengers ought to be able to find out in advance where they can catch their train, when it will leave, where they have to change, and what help or facilities are available for their particular needs. Without this information, some people may lack the confidence to travel at all. All railway passengers like to know, in advance of their journey, where to go when they reach the station and how to find the appropriate train service [3].

Again access is an issue that plays a vital part in the life of persons with disabilities, who are becoming increasingly scared of going outside and do whatever work he/she has to do. We are afraid of stairs, rickety steps, the high-floored buses, the gap between the platform and train in a railway station [4]. In these circumstances the access to the public places like railway station is still a nightmare to the Bangladesh persons with disabilities. Conversely access to public places without barrier-free, making the public places 
and pathways and waiting areas and bus-train terminals is difficult. If persons with disabilities can get to a public places like railway station and pathways and waiting areas and bus terminals easily, it's means that other people also have easy to use these areas easily [5]. However some people with disabilities are understandably unwilling to start a journey until they know that it will be possible for them to complete it reasonably easily. Passengers should be able to find out whether the stations and trains that they intend to use will be accessible to them and should be assured that this information is reliable. Thus accessibility information should be available in a range of formats, including large print, audio and Braille. Besides this information regarding the level of accessibility of all stations must be freely available [6].

\section{Research Objective and Methodology}

The main purpose of this study is to provide valuable information on effective design techniques and standards for ensuring barrier free accessible environment in Kamlapur Railway Station (KRS) in Dhaka city for disabled people. To fulfill this purpose intensive concentration has been given throughout the study to achieve the following specific objectives:

- To identify problem of movement, observe facilities and access deficiencies in station area for disabled people.

- To find out the opinions of accessible environment and barriers in the station area.

- Proposed barrier-free accessible environment design for Kamlapur Railway Station.

However this study has been designed as a survey research where qualitative and quantitative data are combined. Qualitative data have been obtained from written documents, interviews with concerned people and institutions and observations intended for accessible environment for disable people in the railway station. Then quantitative data have been compiled by means of questionnaires intended for disable people. Hence, 93 disable persons living in Dhaka city have been surveyed using random sampling technique where 34 visually impaired persons and 59 wheelchair dependents have been evaluated. The questions have been prepared in 7 interrelated categories: personal information about the disabled person, help requirements, frequency of travel and modal behavior of disable people and opinions of disable people regarding public places. Then the survey has been made using paper based face-to-face question and answer method concerning barriers and accessible environment in Kamlapur railway station, Dhaka; for two months in two deferent times - first one in September 2012 and second one in March 2013. Figure 1 shows the survey location of Kamlapur railway station near Motijheel area. Again to identify problem of movement and barriers in station area the field survey area was carried out with the help of two different kinds of disable people. Lastly in evaluation of the survey data SPSS software package has been used to identify barriers in different locations.

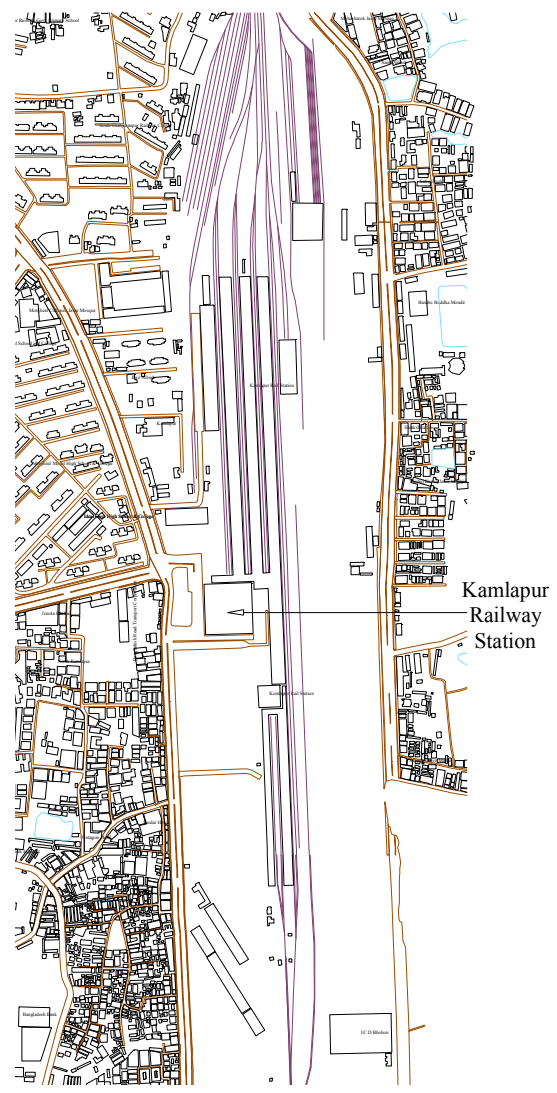

Figure 1. Location of Kamlapur Railway Station.

\section{Identify Barriers and Opinions of Accessible Environment}

Kamalapur Railway Station is the central railway station in Dhaka, Bangladesh. There are 47 local trains, 28 express trains and 24 inter-city trains going through the station, and normally around 50 trains a day. Number of passenger platform is 10, passenger shed is 07 and running lines is 16 . However to identify the present situation in this station field survey was focused on to watch and identifies the barriers and deficiencies regarding accessible environment which was done by the assistance of two groups of disable people. First observed barriers with the help of one wheel chair user about their difficulties to get in and get out the Kamlapur railway station from drooping area to platform area. Then observed barriers with the help of one visual impairment person concerning their complexities to get in and get out from drooping area to platform area. Figure 2 shows ground floor plan and barriers in different location in station area. From field survey six (6) types of barriers were identified within and around the station which were located like B1, B2, B3, B4, B5 and B6 as shown in figure 2. Because of frequent present of rickshaw field survey also identified the rickshaw driving area within the station area for recommending separate rickshaw dropping location. The field survey result explains that around and within station from rickshaw dropping to platform area there was no information of accessible environment for handicapped people. In the 
location B1, B2, B3 and B4 as entry-exit location and position B5 and B6 area for ticketing and information facilities requires a number of accessible requirements for make these location barrier-free. But all these locations including platform area was not accessible for both wheel chair user and visual impairment person. Again location B1,
B3 and B4is designated as rickshaw dropping area, still without any accessible requirements disable people recognized barriers in these locations. To understand this location more closely field survey collect photographs with the help of two groups of handicapped people which illustrates in the following table 1.

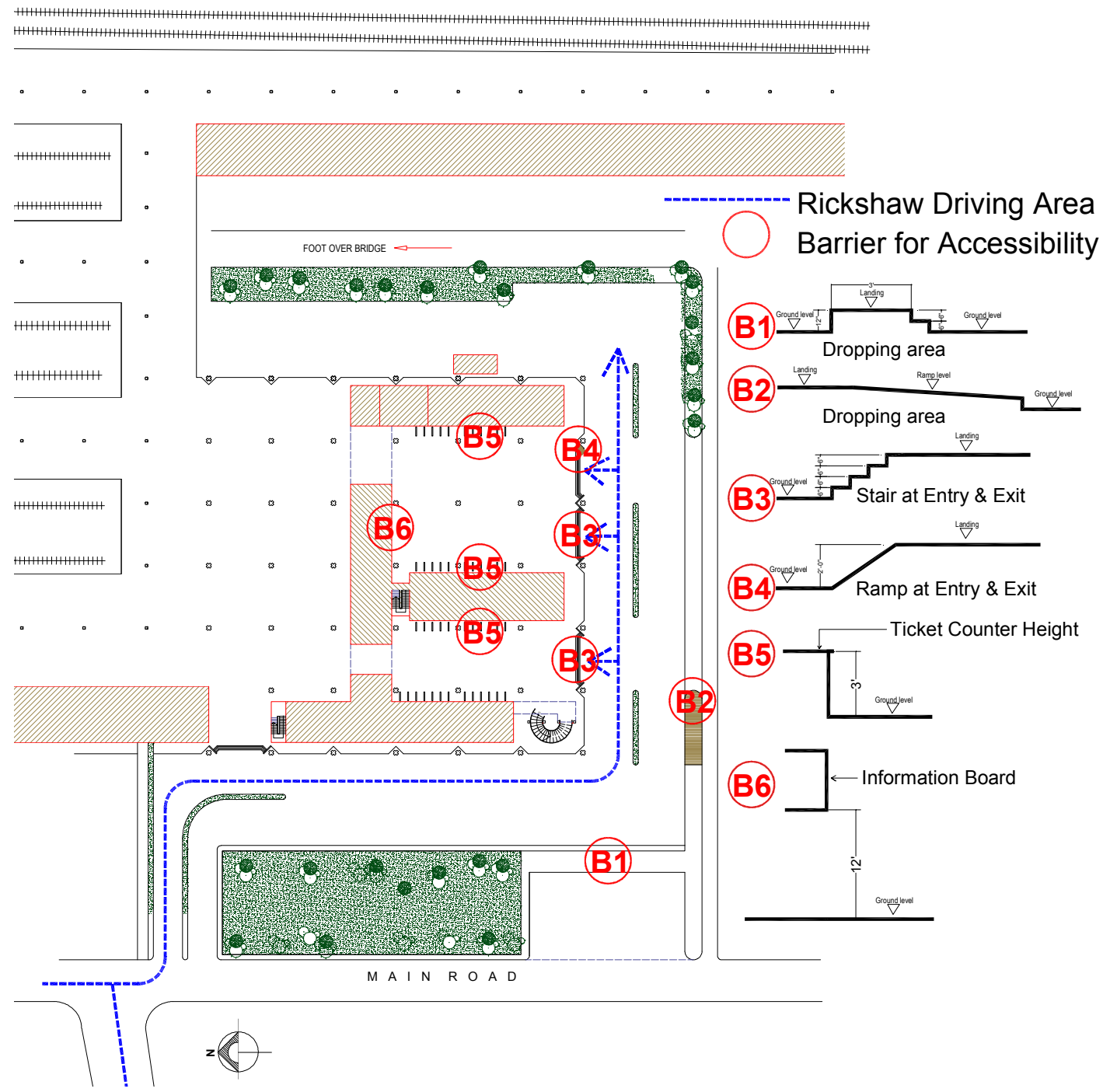

Figure 2. Ground floor plan of Kamlapur railway station and barriers in different location.

Table 1. Barriers in 6 different locations within \& around Kamlapur Railway Station.

\begin{tabular}{|c|c|c|}
\hline Barrier & Location of Barriers & Remarks \\
\hline \multirow{3}{*}{ B1 } & \multirow{3}{*}{$\begin{array}{l}\text { Auto Rickshaw and Rickshaw } \\
\text { dropping area }\end{array}$} & -Sudden steps after dropping from Rickshaw. \\
\hline & & -No sign or color/material change for Blind people \\
\hline & & -Height of Ramp is not standard \\
\hline \multirow[t]{2}{*}{ B2 } & \multirow[t]{2}{*}{ Walking area after dropping } & -Ramp has no handrail \\
\hline & & -Ramp is finished all of a sudden. \\
\hline \multirow{3}{*}{ B3 } & \multirow{2}{*}{ Entry \& Exit level } & -No standard ramp for handicapped people \\
\hline & & -No sign or color change for Blind people \\
\hline & \multirow{3}{*}{ Entry \& Exit level } & -Ramp is very straight\& has no standard \\
\hline \multirow[t]{2}{*}{ B4 } & & -No handrail for ramp \\
\hline & & -No sign for unexpected ramp \\
\hline \multirow{2}{*}{ B5 } & \multirow{2}{*}{ Ticket counter } & -Height is not suitable for handicapped person \\
\hline & & -No different section and information for handicapped person \\
\hline B6 & Before entrance of platform & $\begin{array}{l}\text {-Because of height and Writing style, information is not visible and accessible for } \\
\text { handicapped people }\end{array}$ \\
\hline
\end{tabular}

Source: Author, Field survey, 2013 
In addition field survey also composed with face-to-face question which was associated between kind of disability with help requirement and frequency of travel and opinions of accessible situation of public places as road, city center, railway station, public building and bus terminal to identify barriers for their movement. Next figure 3 explains relation between kind of disability with help requirement and frequency of travel of the respondents. It shows that majority of the respondents needs sometimes help for their movement where wheel chair user $50.8 \%$ and visual impairment

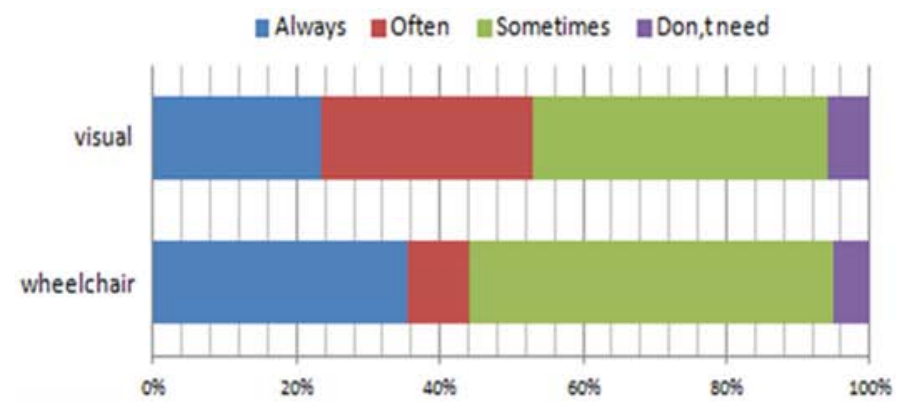

respondent needs $41.2 \%$ sometimes help for their move out. Again 35.6\% wheel chair user and $23.5 \%$ visual impairment respondent needs always help for their move out. Other two requirements for help as often and don't need was not much high compare to others. On the other hand figure 3 once more explain kind of disability and frequency of travel of the respondents. At this point it shows nearly every one move out every day where $84.7 \%$ wheel chair user and $79.4 \%$ visual impairments respondent. Other five requirements for frequency of travel were not much higher than these options.

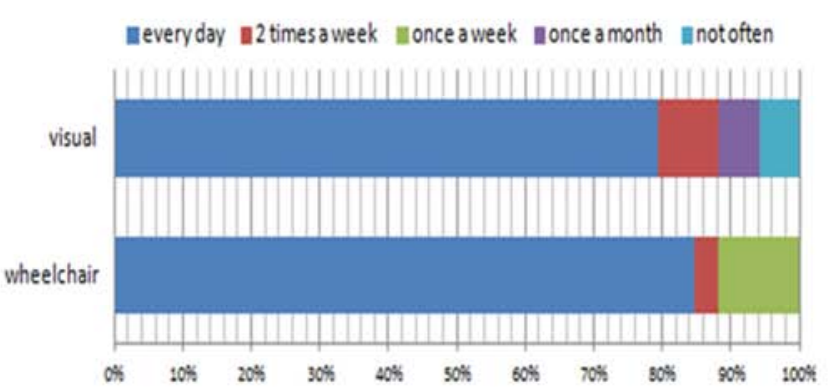

Figure 3. Relation between kind of disability with help requirement and frequency of travel.

Table 2. Cross tabulation analysis of kind of disability and road.

\begin{tabular}{|c|c|c|c|c|c|c|}
\hline & & & \multicolumn{3}{|l|}{ Roads } & \multirow{2}{*}{ Total } \\
\hline & & & Very Inaccessible & Inaccessible & Accessible & \\
\hline \multirow{7}{*}{$\begin{array}{l}\text { Kind of } \\
\text { Disability }\end{array}$} & & Count & 12 & 44 & 3 & 59 \\
\hline & $\begin{array}{l}\text { Wheel Chair } \\
\text { User }\end{array}$ & $\begin{array}{l}\% \text { within Kind of } \\
\text { Disability }\end{array}$ & $20.3 \%$ & $74.6 \%$ & $5.1 \%$ & $100.0 \%$ \\
\hline & & $\%$ of Total & $12.9 \%$ & $47.3 \%$ & $3.2 \%$ & $63.4 \%$ \\
\hline & & Count & 7 & 25 & 2 & 34 \\
\hline & $\begin{array}{l}\text { Visual } \\
\text { Impairment }\end{array}$ & $\begin{array}{l}\% \text { within Kind of } \\
\text { Disability }\end{array}$ & $20.6 \%$ & $73.5 \%$ & $5.9 \%$ & $100.0 \%$ \\
\hline & & $\%$ of Total & $7.5 \%$ & $26.9 \%$ & $2.2 \%$ & $36.6 \%$ \\
\hline & & Count & 19 & 69 & 5 & 93 \\
\hline \multirow[t]{2}{*}{ Total } & & $\begin{array}{l}\% \text { within Kind of } \\
\text { Disability }\end{array}$ & $20.4 \%$ & $74.2 \%$ & $5.4 \%$ & $100.0 \%$ \\
\hline & & $\%$ of Total & $20.4 \%$ & $74.2 \%$ & $5.4 \%$ & $100.0 \%$ \\
\hline \multicolumn{7}{|c|}{ Chi-Square Tests } \\
\hline & & & Value & Df & \multicolumn{2}{|c|}{ Asymp. Sig. (2-sided) } \\
\hline \multicolumn{3}{|c|}{ Pearson Chi-Square } & $.029^{\mathrm{a}}$ & 2 & \multicolumn{2}{|l|}{.985} \\
\hline \multicolumn{3}{|c|}{ Likelihood Ratio } & .029 & 2 & \multicolumn{2}{|l|}{.986} \\
\hline \multicolumn{3}{|c|}{ Linear-by-Linear Association } & .003 & 1 & \multicolumn{2}{|l|}{.958} \\
\hline \multicolumn{3}{|c|}{$\mathrm{N}$ of Valid Cases } & 93 & & & \\
\hline
\end{tabular}

a. 2 cells $(33.3 \%)$ have expected count less than 5 . The minimum expected count is 1.83 .

Table 3. Cross tabulation analysis of kind of disability and city center.

\begin{tabular}{|c|c|c|c|c|c|c|}
\hline & & & \multicolumn{3}{|l|}{ City Center } & \multirow{2}{*}{ Total } \\
\hline & & & Very Inaccessible & Inaccessible & Accessible & \\
\hline \multirow{6}{*}{$\begin{array}{l}\text { Kind of } \\
\text { Disability }\end{array}$} & \multirow{3}{*}{$\begin{array}{l}\text { Wheel Chair } \\
\text { User }\end{array}$} & Count & 23 & 34 & 2 & 59 \\
\hline & & $\begin{array}{l}\% \text { within Kind of } \\
\text { Disability }\end{array}$ & $39.0 \%$ & $57.6 \%$ & $3.4 \%$ & $100.0 \%$ \\
\hline & & $\%$ of Total & $24.7 \%$ & $36.6 \%$ & $2.2 \%$ & $63.4 \%$ \\
\hline & \multirow{3}{*}{$\begin{array}{l}\text { Visual } \\
\text { Impairment }\end{array}$} & Count & 15 & 15 & 4 & 34 \\
\hline & & $\begin{array}{l}\% \text { within Kind of } \\
\text { Disability }\end{array}$ & $44.1 \%$ & $44.1 \%$ & $11.8 \%$ & $100.0 \%$ \\
\hline & & $\%$ of Total & $16.1 \%$ & $16.1 \%$ & $4.3 \%$ & $36.6 \%$ \\
\hline \multirow{3}{*}{ Total } & & Count & 38 & 49 & 6 & 93 \\
\hline & & $\begin{array}{l}\% \text { within Kind of } \\
\text { Disability }\end{array}$ & $40.9 \%$ & $52.7 \%$ & $6.5 \%$ & $100.0 \%$ \\
\hline & & $\%$ of Total & $40.9 \%$ & $52.7 \%$ & $6.5 \%$ & $100.0 \%$ \\
\hline
\end{tabular}




\begin{tabular}{llll}
\hline & City Center & & \\
\cline { 2 - 3 } & Very Inaccessible & Inaccessible & Accessible \\
\hline Chi-Square Tests & & & Asymp. Sig. (2-sided) \\
& Value & Df & .199 \\
Pearson Chi-Square & $3.231^{\mathrm{a}}$ & 2 & .208 \\
Likelihood Ratio & 3.137 & 2 & .802 \\
Linear-by-Linear Association & .063 & 1 & \\
N of Valid Cases & 93 & & \\
\hline
\end{tabular}

a. 2 cells $(33.3 \%)$ have expected count less than 5 . The minimum expected count is 2.19 .

Table 4. Cross tabulation analysis of kind of disability and railway station.

\begin{tabular}{|c|c|c|c|c|c|c|}
\hline & & & \multicolumn{3}{|l|}{ Railway Station } & \multirow{2}{*}{ Total } \\
\hline & & & Very Inaccessible & Inaccessible & Accessible & \\
\hline \multirow{6}{*}{$\begin{array}{l}\text { Kind of } \\
\text { Disability }\end{array}$} & & Count & 37 & 20 & 2 & 59 \\
\hline & $\begin{array}{l}\text { Wheel Chair } \\
\text { User }\end{array}$ & $\begin{array}{l}\% \text { within Kind of } \\
\text { Disability }\end{array}$ & $62.7 \%$ & $33.9 \%$ & $3.4 \%$ & $100.0 \%$ \\
\hline & & $\%$ of Total & $39.8 \%$ & $21.5 \%$ & $2.2 \%$ & $63.4 \%$ \\
\hline & & Count & 14 & 19 & 1 & 34 \\
\hline & $\begin{array}{l}\text { Visual } \\
\text { Impairment }\end{array}$ & $\begin{array}{l}\% \text { within Kind of } \\
\text { Disability }\end{array}$ & $41.2 \%$ & $55.9 \%$ & $2.9 \%$ & $100.0 \%$ \\
\hline & & $\begin{array}{l}\% \text { of Total } \\
\text { Count }\end{array}$ & $\begin{array}{l}15.1 \% \\
51\end{array}$ & $\begin{array}{l}20.4 \% \\
39\end{array}$ & $\begin{array}{l}1.1 \% \\
3\end{array}$ & $\begin{array}{l}36.6 \% \\
93\end{array}$ \\
\hline \multirow{2}{*}{\multicolumn{2}{|c|}{ Total }} & $\begin{array}{l}\text { \% within Kind of } \\
\text { Disability }\end{array}$ & $54.8 \%$ & $41.9 \%$ & $3.2 \%$ & $100.0 \%$ \\
\hline & & $\%$ of Total & $54.8 \%$ & $41.9 \%$ & $3.2 \%$ & $100.0 \%$ \\
\hline \multicolumn{7}{|c|}{ Chi-Square Tests } \\
\hline \multirow{2}{*}{\multicolumn{3}{|c|}{ Pearson Chi-Square }} & Value & Df & \multicolumn{2}{|c|}{ Asymp. Sig. (2-sided) } \\
\hline & & & $4.324^{\mathrm{a}}$ & 2 & .115 & \\
\hline \multicolumn{3}{|c|}{ Likelihood Ratio } & 4.318 & 2 & .115 & \\
\hline \multicolumn{3}{|c|}{ Linear-by-Linear Association } & 3.019 & 1 & .082 & \\
\hline \multicolumn{3}{|c|}{$\mathrm{N}$ of Valid Cases } & 93 & & & \\
\hline
\end{tabular}

a. 2 cells $(33.3 \%)$ have expected count less than 5 . The minimum expected count is 1.10 .

Table 5. Cross tabulation analysis of kind of disability and public building.

\begin{tabular}{|c|c|c|c|c|c|c|}
\hline & & & \multicolumn{3}{|l|}{ Public Building } & \multirow{2}{*}{ Total } \\
\hline & & & Very Inaccessible & Inaccessible & Accessible & \\
\hline \multirow{6}{*}{$\begin{array}{l}\text { Kind of } \\
\text { Disability }\end{array}$} & & Count & 32 & 17 & 10 & 59 \\
\hline & $\begin{array}{l}\text { Wheel Chair } \\
\text { User }\end{array}$ & $\begin{array}{l}\% \text { within Kind of } \\
\text { Disability }\end{array}$ & $54.2 \%$ & $28.8 \%$ & $16.9 \%$ & $100.0 \%$ \\
\hline & & $\%$ of Total & $34.4 \%$ & $18.3 \%$ & $10.8 \%$ & $63.4 \%$ \\
\hline & & Count & 15 & 11 & 8 & 34 \\
\hline & $\begin{array}{l}\text { Visual } \\
\text { Impairment }\end{array}$ & $\begin{array}{l}\% \text { within Kind of } \\
\text { Disability }\end{array}$ & $44.1 \%$ & $32.4 \%$ & $23.5 \%$ & $100.0 \%$ \\
\hline & & $\begin{array}{l}\% \text { of Total } \\
\text { Count }\end{array}$ & $\begin{array}{l}16.1 \% \\
47\end{array}$ & $\begin{array}{l}11.8 \% \\
28\end{array}$ & $\begin{array}{l}8.6 \% \\
18\end{array}$ & $\begin{array}{l}36.6 \% \\
93\end{array}$ \\
\hline \multirow{2}{*}{\multicolumn{2}{|c|}{ Total }} & $\begin{array}{l}\% \text { within Kind of } \\
\text { Disability }\end{array}$ & $50.5 \%$ & $30.1 \%$ & $19.4 \%$ & $100.0 \%$ \\
\hline & & $\%$ of Total & $50.5 \%$ & $30.1 \%$ & $19.4 \%$ & $100.0 \%$ \\
\hline \multicolumn{7}{|c|}{ Chi-Square Tests } \\
\hline \multicolumn{3}{|c|}{ Pearson Chi-Square } & $1.009^{\mathrm{a}}$ & 2 & .604 & \\
\hline \multicolumn{3}{|c|}{ Likelihood Ratio } & 1.005 & 2 & .605 & \\
\hline \multicolumn{3}{|c|}{ Linear-by-Linear Association } & .989 & 1 & .320 & \\
\hline \multicolumn{3}{|c|}{$\mathrm{N}$ of Valid Cases } & 93 & & & \\
\hline
\end{tabular}

a. 0 cells $(.0 \%)$ have expected count less than 5 . The minimum expected count is 6.58 .

Table 6. Cross tabulation analysis of kind of disability and bus terminal.

\begin{tabular}{|c|c|c|c|c|c|c|}
\hline & & & \multicolumn{3}{|l|}{ Bus Terminal } & \multirow{2}{*}{ Total } \\
\hline & & & Very Inaccessible & Inaccessible & Accessible & \\
\hline \multirow{4}{*}{$\begin{array}{l}\text { Kind of } \\
\text { Disability }\end{array}$} & \multirow{3}{*}{$\begin{array}{l}\text { Wheel Chair } \\
\text { User }\end{array}$} & Count & 29 & 16 & 14 & 59 \\
\hline & & $\begin{array}{l}\% \text { within Kind of } \\
\text { Disability }\end{array}$ & $49.2 \%$ & $27.1 \%$ & $23.7 \%$ & $100.0 \%$ \\
\hline & & $\%$ of Total & $31.2 \%$ & $17.2 \%$ & $15.1 \%$ & $63.4 \%$ \\
\hline & Visual & Count & 16 & 10 & 8 & 34 \\
\hline
\end{tabular}




\begin{tabular}{|c|c|c|c|c|c|}
\hline & & \multicolumn{3}{|l|}{ Bus Terminal } & \multirow{2}{*}{ Total } \\
\hline & & Very Inaccessible & Inaccessible & Accessible & \\
\hline \multirow[t]{5}{*}{ Impairment } & $\begin{array}{l}\text { \% within Kind of } \\
\text { Disability }\end{array}$ & $47.1 \%$ & $29.4 \%$ & $23.5 \%$ & $100.0 \%$ \\
\hline & $\%$ of Total & $17.2 \%$ & $10.8 \%$ & $8.6 \%$ & $36.6 \%$ \\
\hline & Count & 45 & 26 & 22 & 93 \\
\hline & $\begin{array}{l}\% \text { within Kind of } \\
\text { Disability }\end{array}$ & $48.4 \%$ & $28.0 \%$ & $23.7 \%$ & $100.0 \%$ \\
\hline & $\%$ of Total & $48.4 \%$ & $28.0 \%$ & $23.7 \%$ & $100.0 \%$ \\
\hline \multicolumn{6}{|l|}{ Chi-Square Tests } \\
\hline \multicolumn{2}{|l|}{ Pearson Chi-Square } & $.060^{\mathrm{a}}$ & 2 & \multicolumn{2}{|c|}{.970} \\
\hline \multicolumn{2}{|l|}{ Likelihood Ratio } & .060 & 2 & \multicolumn{2}{|l|}{.970} \\
\hline \multicolumn{2}{|l|}{ Linear-by-Linear Association } & .012 & 1 & \multirow{2}{*}{\multicolumn{2}{|c|}{.914}} \\
\hline $\mathrm{N}$ of Valid Cases & & 93 & & & \\
\hline
\end{tabular}

a. 0 cells $(.0 \%)$ have expected count less than 5 . The minimum expected count is 8.04 .

Once more above table 2, table 3, table 4, table 5 and table 6 shows opinions concerning accessible environment of public places as road, city center, railway station, public building and bus terminal in Dhaka city. Here three types of opinion similar to very inaccessible (cannot travel without assistance), inaccessible (can be travel without assistance) and accessible were considered as the situation of accessible environment. These above tables explain that both wheel chair user and visual impairment respondents considered railway station was highest $54.8 \%$ very inaccessible (cannot travel without assistance) and roads were highest $74.2 \%$ inaccessible (can be travel without assistance) situation compare to other public places regarding accessible environment. It also explains that all these public places were very few ratio of accessible situation for both respondents. Then figure 4 and figure 5 shows railway station was very inaccessible for $62.7 \%$ wheel chair user and bus terminal was very inaccessible for $47.1 \%$ visual impairments respondents. Then roads were decided as most inaccessible for both kinds of disable respondents, which was $74.6 \%$ for wheel chair user and $73.5 \%$ visual impairments respondents.

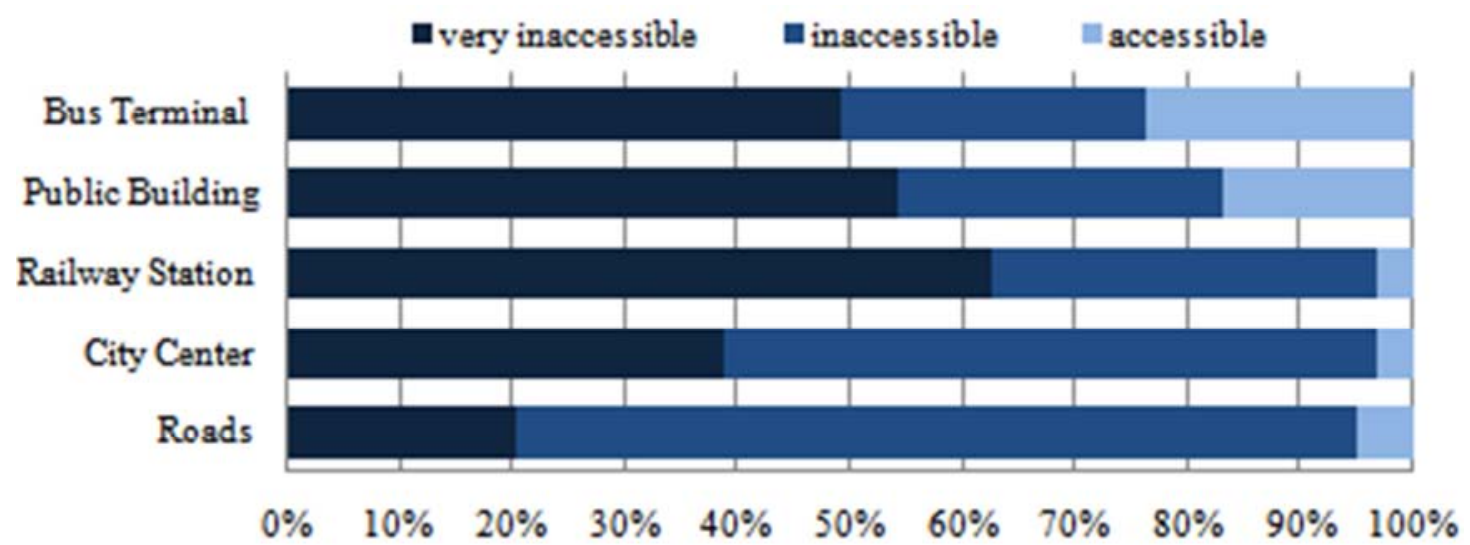

Figure 4. Opinion of wheel chair user about public places.

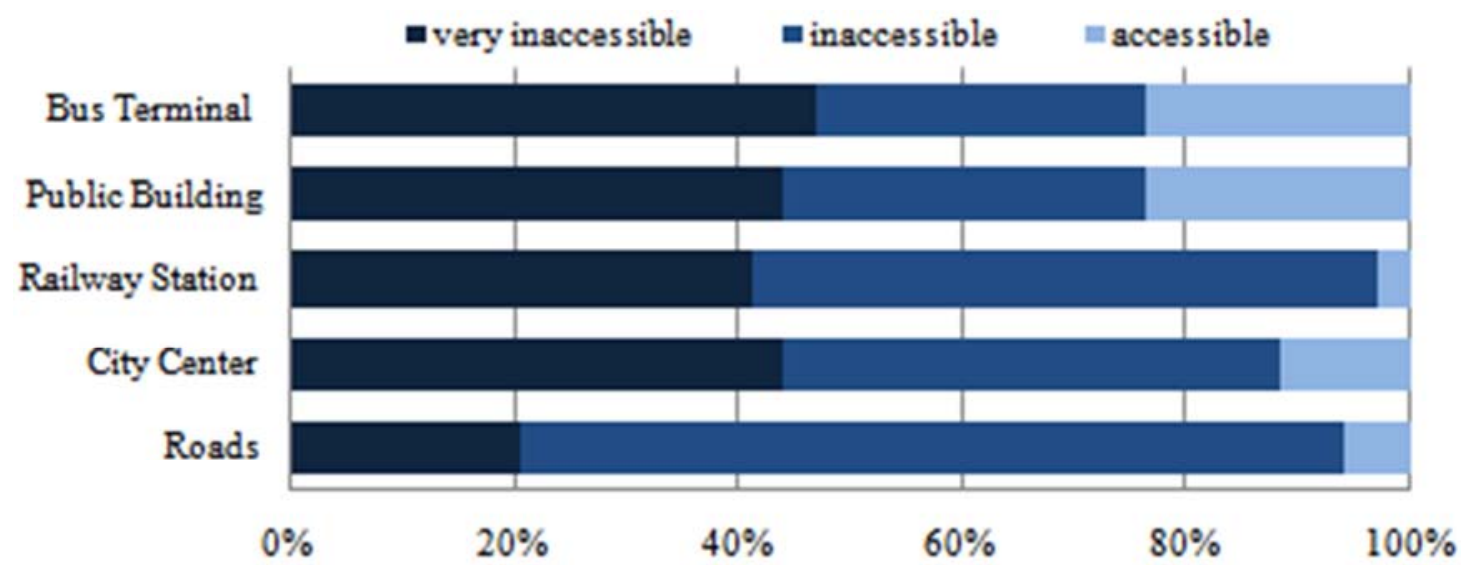

Figure 5. Opinion of visual impairment respondents about public places. 


\section{Proposed Barrier-Free Design for Accessible Environment Within station Area}

Consequence explains that as a public place the Kamlapur railway station has very inaccessible environment for disable people compare to other places. Due to pay no attention around and within the station area regarding barrier-free accessible environment, this area is not obliging for disable people. Figure 6 shows proposed location and design as to create accessible environment within the station's ground floor area. However to make this area barrier-free, this study considered 2010 ADA (Americans with Disabilities Act) barrier free design standards for recommending following proposal which are then illustrated in figures $7,8,9,10$ and 11 successively. For proposing barrier-free design within the station area, this study again focus on the following recommendations and standards (table 7) -

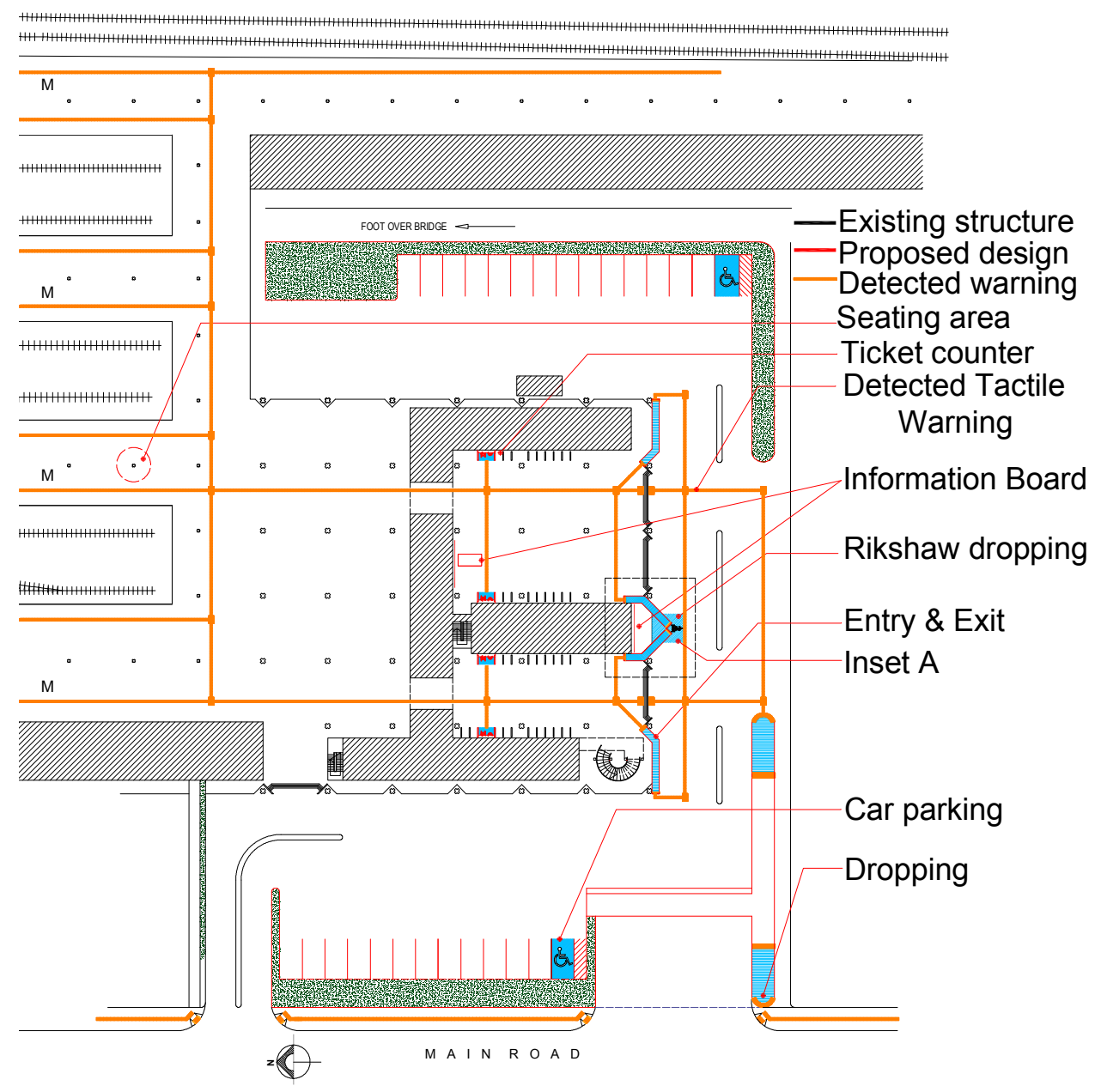

Figure 6. Proposed location and barrier free design for Kamlapur Station.
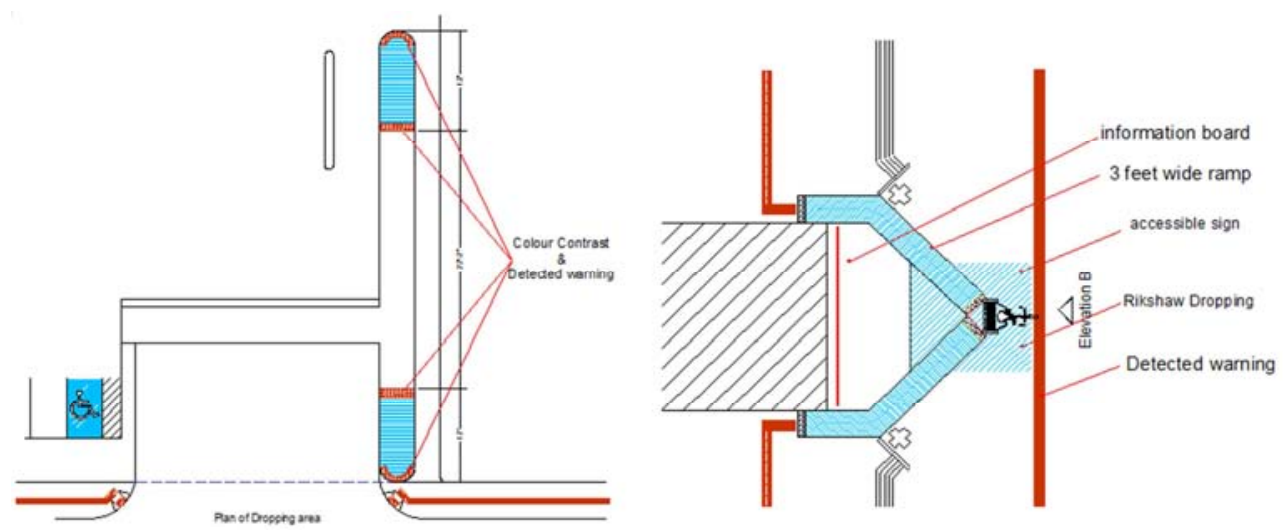

Figure 7. Proposed design for rickshaw and auto rickshaw dropping area. 

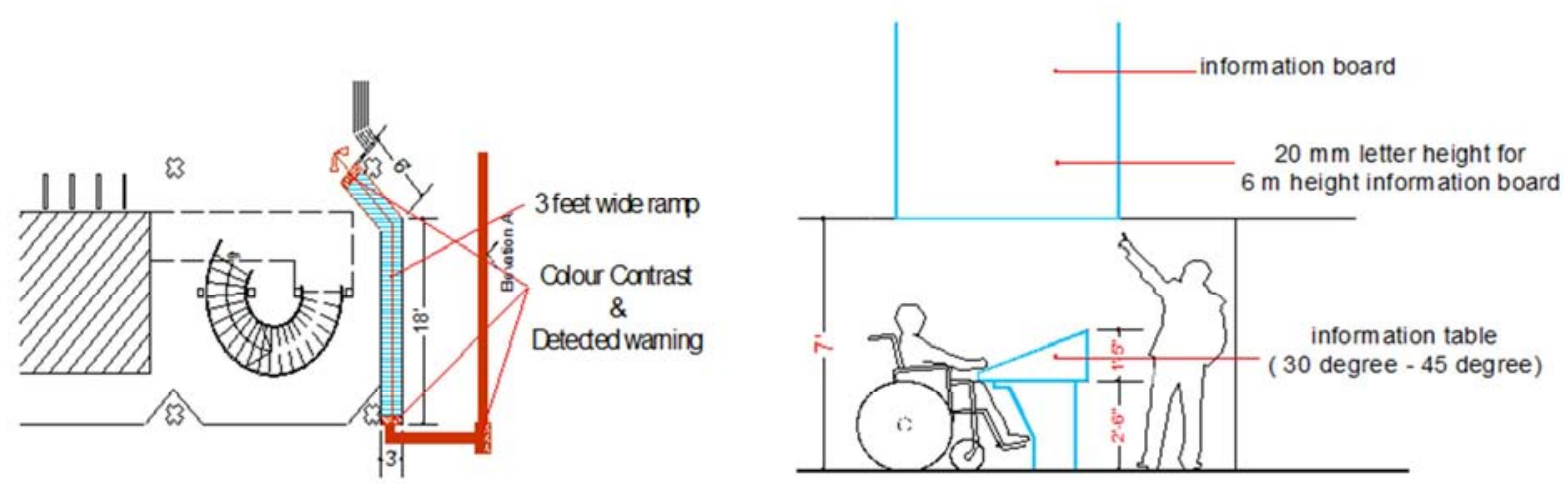

Figure 8. Proposed design for wheel chair user, information board and table.

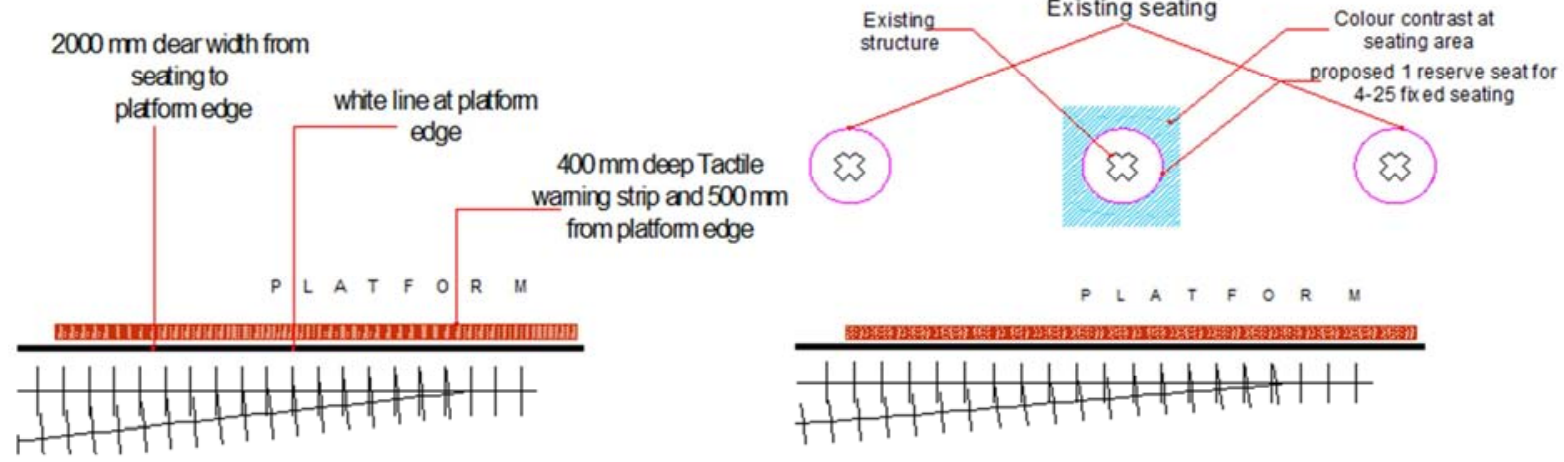

Figure 9. Proposed design for detected warning and reserved seating.

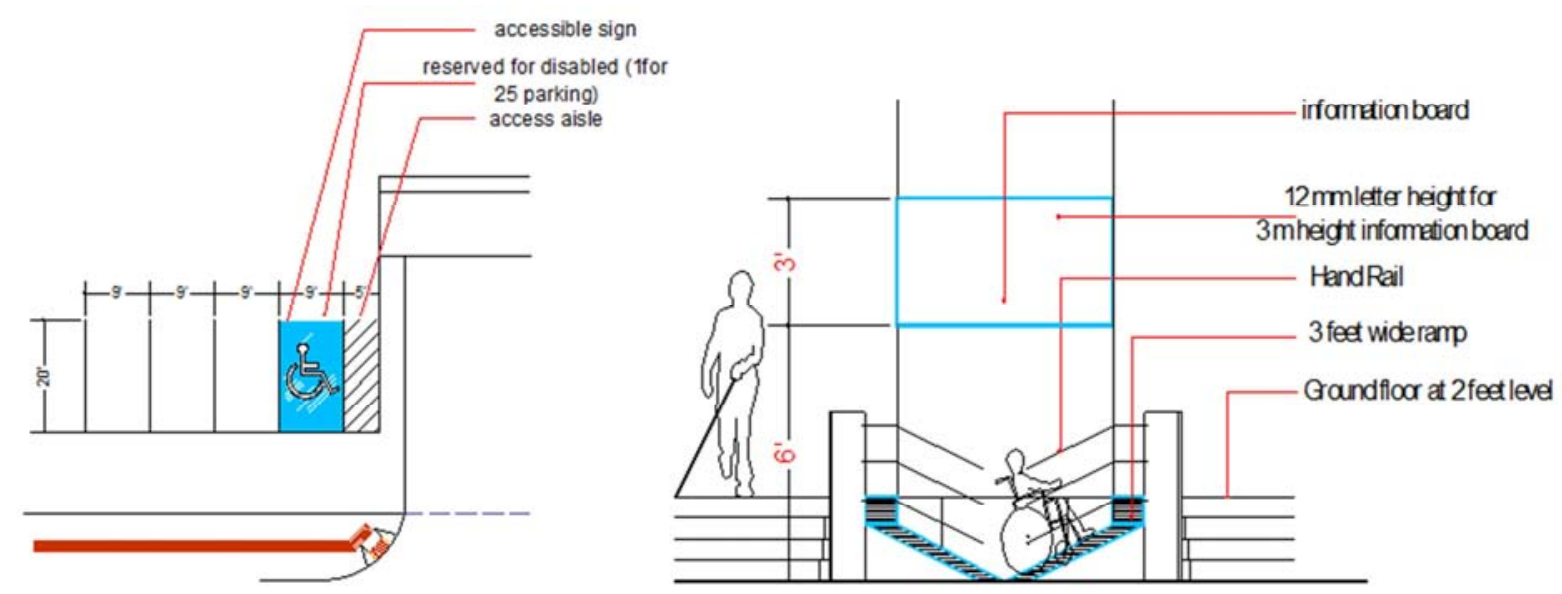

Figure 10. Proposed design for reserved car parking and entry-exit area.

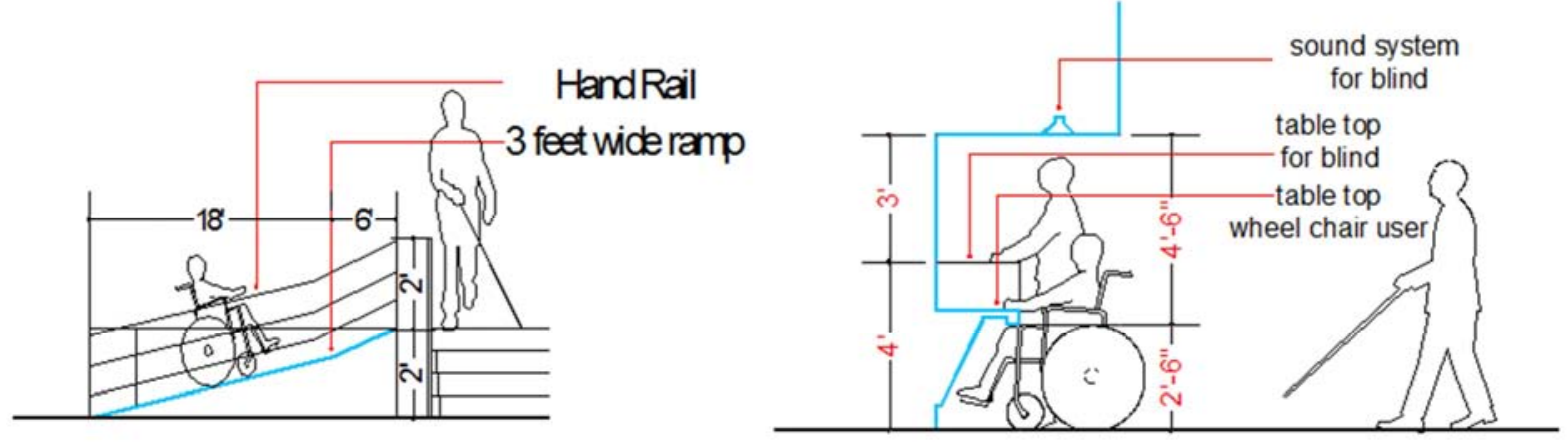

Figure 11. Proposed design for entry-exit and ticket counter area. 
Table 7. ADA 2010 (Americans with Disabilities Act) barrier free design standard [7], [8].

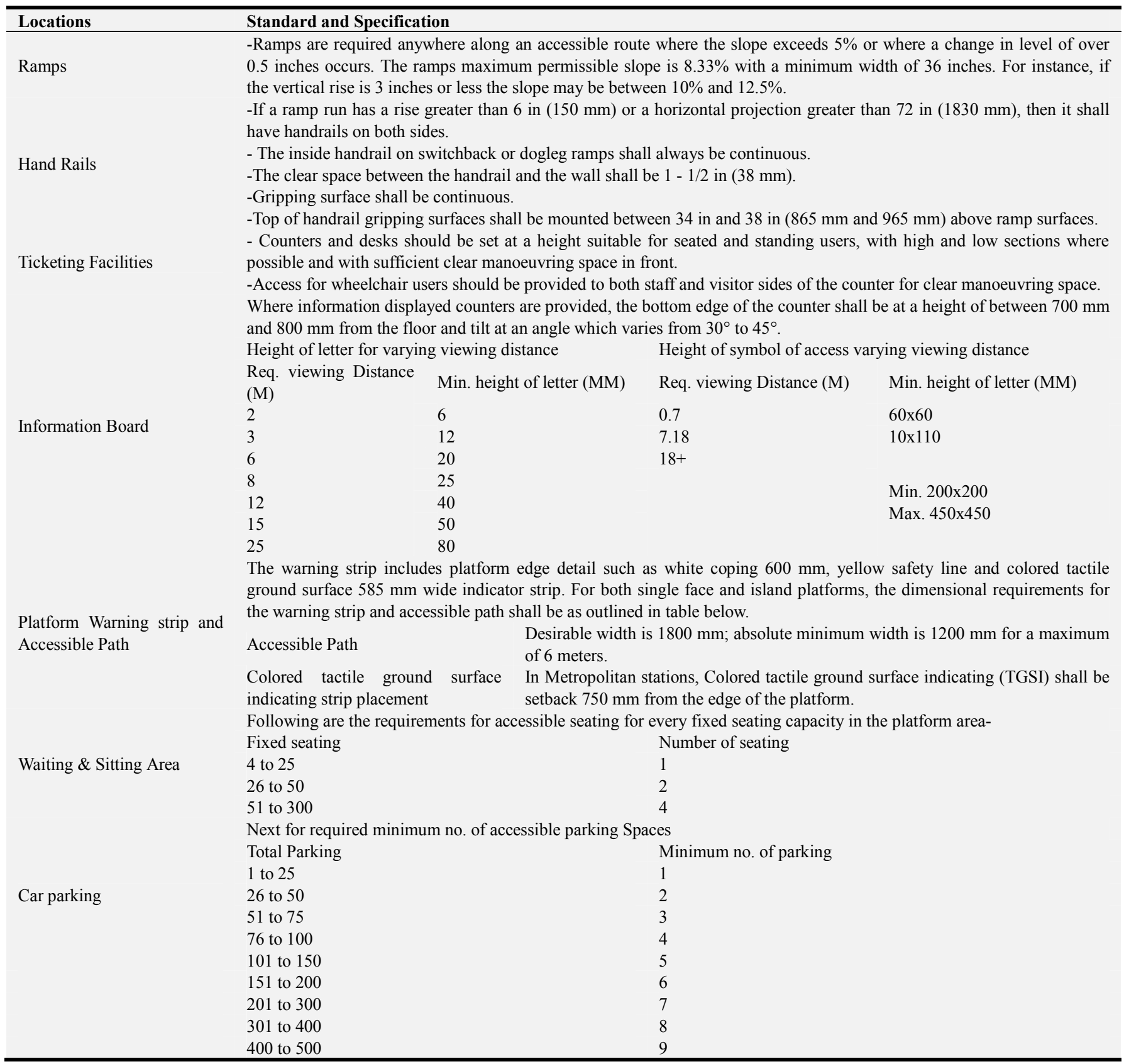

Source: ADA 2010, Barrier free Design Standard

\section{Conclusion}

Kamlapur railway station is the biggest railway station in Bangladesh, but accessible environment is not significant from the point of disable people. Presently from dropping to entry-exit there are no indication of accessible features are establishing so far. As of this study demonstrates that this station was very inaccessible (cannot travel without assistance) for both wheel chair and visual impairment user compare to other public places. It shows total $62.7 \%$ wheel chair user decided regarding very inaccessible (cannot travel without assistance) and $33.9 \%$ and $3.4 \%$ wheel chair user considered as inaccessible (can be travel without assistance) and accessible situation correspondingly for getting into train. On the other hand study shows total $55.9 \%, 41.2 \%$ and $2.9 \%$ visual impairment person measured that Kamlapur railway station has inaccessible (can be travel without assistance), very inaccessible (cannot travel without assistance) and accessible situation respectively. In conclusion it is found that the practice of accessibility issues in Dhaka city is very inconsequential. Thus proper planning in public places for disable people must be increased with provided awareness about accessible environment. Then believe should be grow among disable people that accessibility is their right. 


\section{References}

[1] Imrie, R., (2000), Responding to the Design Needs of Disabled People, Journal of Urban Design, Vol. 5, No. 2, Pp. 199-219.

[2] Iwarsson, S., and Staeh, A., (2003), 'Accessibility, usability and universal design - positioning and definition of concepts describing person-environment relationships', Disability and Rehabilitation, Vol. 25, No. 2, Pp. 57-66.

[3] Hassan, S., Sham, M., Awang, M., Yaman, R., 2012, Accessibility for Disabled in Public Transportation Terminal, Volume 35, Pp 89-96.

[4] Qureshi, A., 2007, Inclusive Transportation Can Improve Lives of Disabled People, DIIR, India.

[5] Accessible Train Station Design for Disabled People: A Code of Practice, 2011, Version 03, Department for Transport and Transport Scotland.

[6] Suen, L. and C. Mitchell., Accessible Transport and Mobility in TRB Proceedings, Committee on Accessible Transportation and Mobility. Paper A1E09.

[7] ADA Standards for Accessible Design, 1994, 28 CFR Part 36, Department of Justice.

[8] Peter, W., and Axelson, (1999), 'Designing Sidewalks and Trails for Access; Part I of II: Review of Existing Guidelines and Practices', United States Access Board, America.

[9] Topping, B. and Feet, M., (2010), 2010 City of Winnipeg, Accessibility Design Standards, Designable Environments, Pp-167-175.

[10] Abir, A. K. M. and Hoque, M. S., (2011), A Study on Mobility Problem of Disabled People in Dhaka City, $4^{\mathrm{TH}}$ Annual Paper Meet and $1^{\mathrm{ST}}$ Civil Engineering Congress, December 22-24, 2011, Dhaka, Bangladesh, ISBN: 978-98433-4363-5.

[11] Lacey, A, (2004), Designing for Accessibility, an Essential Guide for Public Buildings, Centre for Accessible Environments and RIBA Enterprises, ISBN: 185946143 3, Pp-13-52. 